\title{
Web-Based Decision Support Systems Application of Stock Recommendation Using Bayesian Methods
}

\section{Aplikasi Sistem Pendukung Keputusan Rekomedasi Stok Berbasis Web dengan Metode Bayesian}

\author{
Nina Sevani *, Maria Ariesta \\ Informatics Engineering Department \\ Faculty of Engineering and Computer Science \\ Krida Wacana Christian University \\ Indonesia
}

\begin{abstract}
We propose an application that can support traders by providing recommendation about the right stock transaction. The expected impact from this application is to reduce the risk of loss, even achieve the maximum profit for traders who use this application. Recommendation that resulted by application is based on Bayesian methods calculation and four technical analysis indicators that most commonly used by stock experts, i.e. Bollinger Bands, Moving Average Convergence Divergence (MACD), Relative Strength Index (RSI), and Stochastic Oscillator. Methodology used in this paper consists of data collection, data analysisa, application design, implementation, and testing. From the results of application testing, the accuracy of the application is $87,37 \%$.
\end{abstract}

keywords: Decision support systems, Stock recommendation, Bayesian methods

\begin{abstract}
Abstrak
Pada tulisan ini, sebuah aplikasi yang dapat mendukung pemain saham dengan memberikan saran mengenai transaksi saham yang tepat diusulkan. Dampak yang diharapkan dengan adanya aplikasi ini adalah mengurangi resiko kerugian bahkan mencapai keuntungan yang maksimal bagi pemain saham yang menggunakannya. Saran yang dihasilkan aplikasi diperoleh berdasarkan perhitungan dengan metode Bayes dan empat indikator analisis teknikal yang paling sering digunakan menurut pakar saham, yaitu Bollinger Bands, Moving Average Convergence Divergence (MACD), Relative Strength Index (RSI), dan Stochastic Oscillator. Metodologi yang digunakan adalah pengumpulan data, analisis data, perancangan, implementasi, dan pengujian. Dari hasil pengujian aplikasi, diketahui tingkat keakuratan aplikasi sebesar 87,37\%.
\end{abstract}

kata kunci: Sistem penunjang keputusan, Rekomendasi saham, Metode Bayes

\section{INTRODUCTION}

Stock is one of lots investment options that increasingly in demand by all circles [1]. Stock investments processed by sell and buy stocks to get a part ownership of the companies. Investors profits obtained from the difference of stock buy value and sell value. Stock investor is better known also as a trader. To get the maximum profits, traders must buy or sell stock in the right time. The right

${ }^{*}$ Corresponding Author. Tel: +6222-7564108

Email: giselaninsgmail.com

Received: 24 Mar 2014; revised: 16 Apr 2014; accepted: 23

Apr 2014

Published online: 30 May 2014

(c) 2014 INKOM 2014/14-NO302 times means traders buy stock when it is in the lowest price and sell stock when it is in the highest price over period [2]. The changes of stock price or stock value are influenced by several factors, namely internal factors of company and external factors such as announcements of government and world politic economy development. Thus before do some stock transaction, trader must analyze changes of stock price, so the transactions did can give maximum profits and avoid any risks of loss. There are two kind of analysis for trader, fundamental analysis and technical analysis [3]. For long term investation, fundamental analysis is better than technical analysis. Technical analysis helps to predict the direction of share price movement through the study of post market data, primarily 
price and volume [4]. But for short term investation, fundamental analysis is better [5]. But, the problem is not easy to analyze changes of stock price, especially for beginner trader. Even the accuracy of analyze result by human expert in stock is only $70 \%$. Beside skill for analyze the stock price, trader can minimize the risk and maximaze the profit for every transaction they made if they can get solution from the expert about the trend of stock price in the future [6].

To solve this problem, this paper proposes a decision support system application that can give traders recommendation about transaction will be taken, whether buy, sell, or just hold stocks. That recommendation obtained from combination calculation of technical analysis and Bayesian methods. Technical analysis is an analysis method that used often in stock trade by calculates combination of open price, closing price, highest price, and lowest price of stock with some formula [7]. Technical analysis is commonly figured in a chart form. Technical analysis includes hundreds of indicators. The use of some indicators before decision making is one of the wiser technical analysis [8]. The preliminary study shown that several technical tools can be used togeter [9]. Some indicators that mostly used by stock expert according to broker of PT Kresna Securities are Bollinger Bands, Moving Average Convergence Divergence (MACD), Relative Strength Index (RSI), and Stochastic Oscillator. Traders are often inclined to use one indicator with other indicators to see if there is a confirmation. In particular, the use of an oscillator will often be coupled with a nonoscillator indicator. If these indicators confirm the recommendation of the other one indicator, the trader will have greater evidence that the forecast is correct. Therefore, technical analysis indicators used in this application for calculate are four indicators that have been mentioned. The reason of use four indicators is because not all stocks match with one type of indicator and some previous reason mentioned. This application also provide chart of technical analysis to help traders in monitoring historical stock data and support their analysis.

Decision support system application that will be developed is an application based on web, which can be run by all browser application. The advantages from develop web based application are can used on many platform and also can accessed wherever without limit of space and time. This application is developed especially for beginner trader to support them in reading technical analysis indicator chart and making stock transaction decision. But still, this application is also useful for expert traders to get the best profit. This decision support system application just give traders a recommendation about the best transaction according to calculation indicators with Bayesian methods, but decision is free taken by all traders.

This paper is organised as follows: in Section 2, we present some indicators for stock recommendation and Bayesian methods. In Section 3, we present our methodology in building the Decision Support System. In Section 4, the implementation and performance of the system are presented. In Section 5 , we conclude our paper.

\section{INDICATORS FOR STOCK RECOMMENDATION AND BAYESIAN METHODS}

In this section, we will revisit some indicators for stock recommedation and the definition of Bayesian methods.

\subsection{Stock Technical Analysis Indicators}

Technical analysis use historical stock data to be processed and produce buy and sell signal in a chart form [10]. Technical analysis has hundreds indicators that created by professionals with different mindset. The result of their analysis is different each other. Indicators of technical analysis used in application developed are Bollinger Bands, Moving Average Convergence Divergence (MACD), Relative Strength Index (RSI), and Stochastic Oscillator. Each indicator has a different formula to get a chart line, buy signals, and sell signals of stock.

The first technical analysis indicator used is Bollinger Bands. Bollinger Bands is one of technical analysis indicator tool invented by John Bollinger in the 1980s, and a term trademarked in 2011. Bollinger Bands use standard deviation in calculation instead of a fixed percentage. It is displayed as three bands that called middle band, upper band, and lower band (Fig. 1) [11]. The purpose of Bollinger Bands is to provide a relative definition of high and low. By definition, prices are high at the upper band and low at the lower band. This indicator is useful in comparing price action to the action of indicators to arrive at systematic trading decisions.

Formula to create middle band, upper band, and lower band can be written in Equation 1, 2, and 3.

$$
\begin{gathered}
\text { Middle Band }=\mathrm{SMA}_{20} \\
\text { Upper Band }=\mathrm{SMA}_{20}+\left(\mathrm{STDEV}_{20} \times 2\right) \\
\text { Upper Band }=\mathrm{SMA}_{20}-\left(\mathrm{STDEV}_{20} \times 2\right)
\end{gathered}
$$

Where $\mathrm{SMA}_{20}$ is an average of closing price of stocks for last 20 days, and STDEV 20 (Standard 


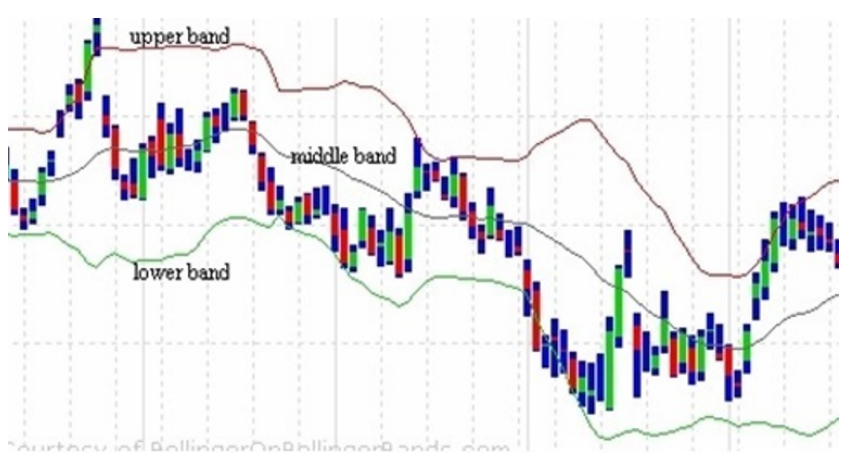

Figure 1. Sample Chart of Bollinger Bands

Deviation of Price) is a standard deviation of closing price of stocks for last 20 days. STDEV formula can be written as follows:

$$
\operatorname{STDEVP}=\sqrt{\frac{\sum(x-\bar{x})}{n}}
$$

Where $x$ is the closing price of stocks, $\bar{x}$ is $\mathrm{SMA}_{20}$, and $n$ is a total days calculated (in this case, total days calculated is 20 days).

The use of Bollinger Bands varies widely among traders. In decision support system application of stock recommendation, buy signals will appear when price touches the lower band and exit when price breaks above the middle band. Sell signals will appear when price at upper band falls below the middle band. Moreover, the use of Bollinger Bands is not confined to stock traders. These signals of buy and sell stock is only as recommendation, and decision is free taken by each trader.

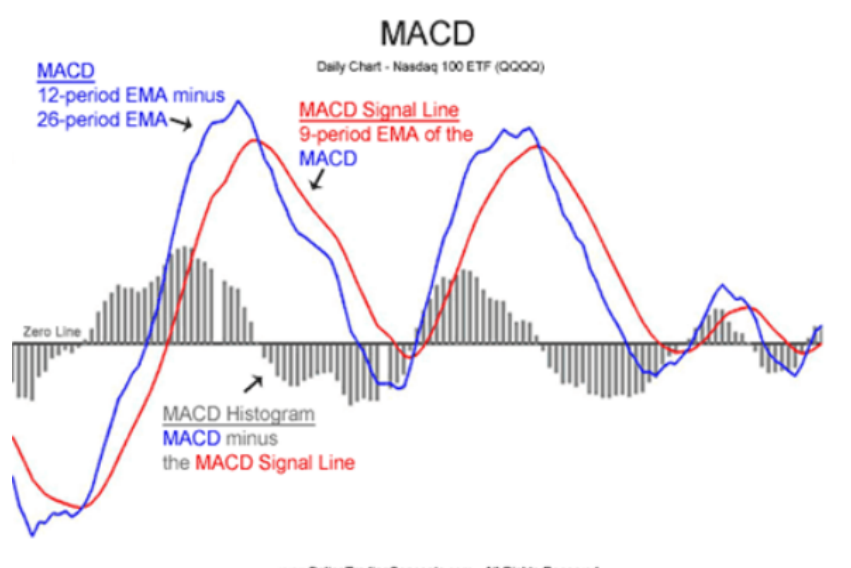

Figure 2. Sample Chart of MACD

The second analysis technical indicator used is Moving Average Convergence Divergence (MACD). MACD is created by Gerald Appel in the late 1970s, and it is one of the simplest and most effective momentum indicators available [12]. The MACD turns two trend-following indicators, moving average, into a momentum oscillator by subtracting the longer moving average from the shorter moving average. As a result, the MACD offers the best of both worlds, that is trend following and momentum. MACD fluctuates above and below the zero line as the moving averages converge, cross, and diverge. MACD is a collection of two signals calculated from historical price data, most often the closing price. The signal is shaped in a line form. These two signal lines are the MACD Line and Signal Line [11] (Figure 2). Calculation to create MACD line and signal line can be written as follows in Equation 5 and 6 .

$$
\mathrm{MACD}_{\text {Line }}=\mathrm{EMA}_{12} \mathrm{EMA}_{26}
$$

$$
\begin{aligned}
\text { Signal }_{\text {Line }}= & 2 /(9+1) \times\left(\operatorname{MACD}_{\text {Line }}-\operatorname{Signal}_{P}\right) \\
& +\operatorname{Signal}_{P}
\end{aligned}
$$

Where $\mathrm{EMA}_{12}$ is an exponential moving average of closing price of stock for 12 days, $\mathrm{EMA}_{26}$ is an exponential moving average of closing price of stock for 26 days, and $\mathrm{Signal}_{P}$ is a Signal Line on one day before.

$\mathrm{EMA}_{12}$ and $\mathrm{EMA}_{26}$ can be calculated with formula as follows:

$$
\begin{aligned}
& \text { EMA }_{12}=2 /(12+1) x(C-\text { EMAP })+\text { EMAP } \\
& \text { EMA }_{26}=2 /(26+1) x(C-\text { EMAP })+\text { EMAP }
\end{aligned}
$$

Where $C$ is the closing price of stock on the latest day, EMAP in $\mathrm{EMA}_{12}$ formula is the $\mathrm{EMA}_{12}$ one day before, and EMAP in $\mathrm{EMA}_{26}$ formula is the $\mathrm{EMA}_{26}$ one day before.

In decision support system application of stock recommendation, buy signals will appear when the MACD Line has a negative value and crosses above the Signal Line. Sell signals will appear when the MACD Line has a positive value and crosses below the Signal Line [11].

The third analysis technical indicator used is Relative Strength Index (RSI). Developed by J. Welles Wilder, RSI is one of the most commonly used technical indicators to gauge momentum on stock markets and it has proven remarkably accurate over the past few months at predicting turning points for key equity indexes in North America. The RSI is popular among investors because it is fairly simple to read and easy to understand. RSI is an oscillator that measures current price strength in relation to previous prices [10]. RSI calculation is based on 14 days. Mathematically, the RSI formula can be written as follows in Equation 9. 


$$
\mathrm{RSI}=1-\left(\frac{100}{1+\mathrm{RS}}\right)
$$

Where $\mathrm{RS}=$ average gain/average loss. average gain is the average of gains over the past 14 days, and average gain is the average of losses over the past 14 days. Losses are expressed as positive values, not negative values.

The index measures momentum on a scale of zero (0) to 100 . RSI that has reading below 30 is considered oversold and a reading above 70 indicated an overbought position. In decision support system application of stock recommendation, buy signals will appear when the RSI crosses above the oversold line (30), and sell signals will appear when the RSI crosses below the overbought line (70) [11]. The sample chart of RSI is shown in Figure 3.

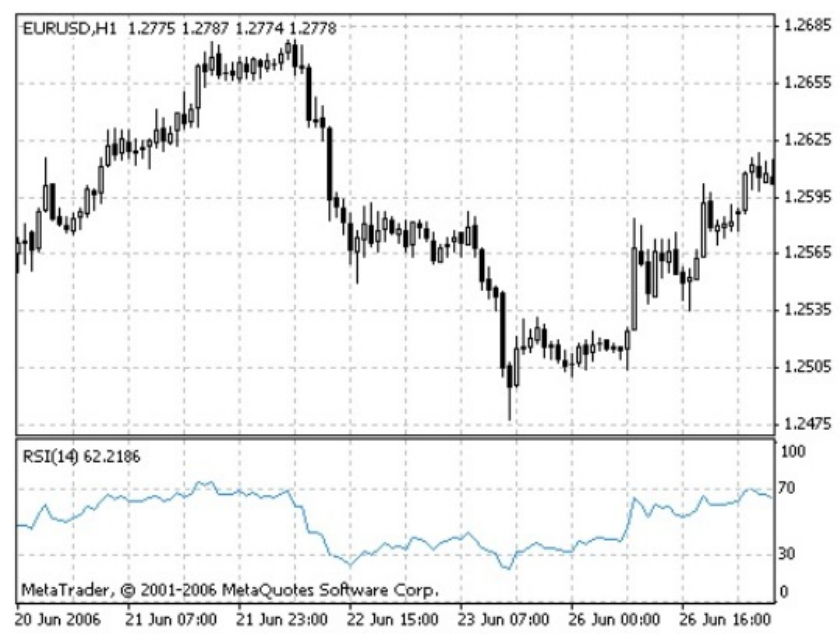

Figure 3. Sample Chart of RSI

The fourth analysis technical indicator used is Stochastic Oscillator. Developed by George C. Lane in the late 1950s, the Stochastic Oscillator is a momentum indicator that shows the location of the close relative to the high-low range over a set number of periods [13]. Stochastic Oscillator will give an anticipatory signal in combination between $\% K$ line and $\% D$ line (Figure 4). Mathematically, the Stochastic Oscillator is defined in Equation 10.

$$
\% K=\frac{C-L_{14}}{H_{14}-L_{14}} \times 100
$$

Where $C$ is the current closing price of stock, $L_{14}$ is respectively the lowest price over the last 14 days, and $H_{14}$ is respectively the highest price over the last 14 days. $\% D$ is obtained from calculate average of $\% K$ over the last 3 days.

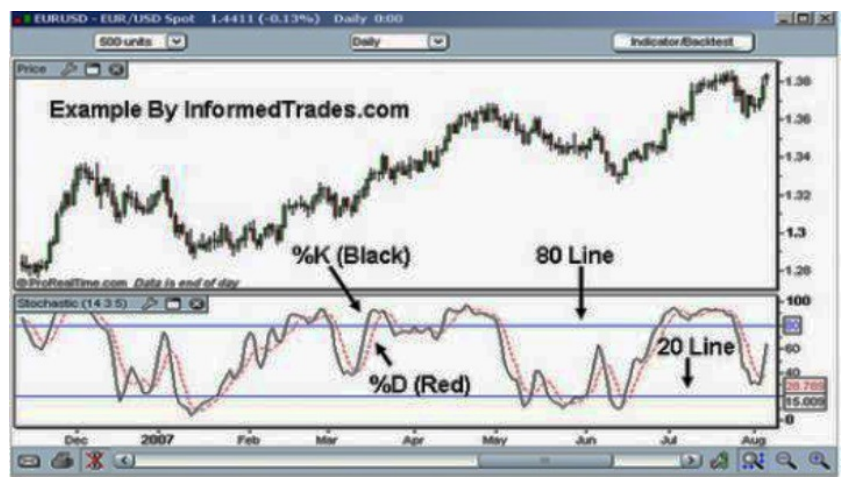

Figure 4. Sample Chart of Stochastic Oscillator

Buy signals and sell signals can be seen from the line formed by $\% K$ and $\% D$. In decision support system application of stock recommendation, buy signals will appear when $\% K$ line crossed above $\% D$ line when $\% K$ value is smaller or equals to 20. This condition indicates trend of bullish, which is the stock prices are potentially overbought and seem likely to rise. Sell signals will appear when $\% K$ line crosses below $\% D$ line when the value of $\% K$ is greater or equals to 80 . This condition indicates trend of bearish, which is the stock prices are potentially overbought and seem likely to going down [11].

\subsection{Bayesian Methods}

Named for Thomas Bayes, Bayesian logic is a branch of logic applied to decision making and inferential statistics that deals with probability inference. The Bayesian method is using the knowledge of prior events to predict future events. Bayesian methods involving statistical methods that assign probabilities or distributions to events or parameters based on experience or best guesses before experimentation [14].

Generally, the calculation formula of Bayesian methods defined as follows:

$$
\text { Prob }=\sum_{j=1}^{n} \text { Value }_{j} \times\left(K_{j}\right)
$$

Where $j$ is a variable that indicates sequence number of criteria, and $\mathrm{n}$ is a variable that indicates total of criteria. In decision support system application of stock recommendation, the criteria are technical analysis indicators. It means, $j=$ 1 indicates indicator Bollinger Bands, $j=2$ indicates MACD, $j=3$ indicates RSI, and $j=4$ indicates Stochastic Oscillator. Value ${ }_{j}$ is the result of calculation based on each indicator, and $K_{j}$ is the weight of criteria probability. In this case, $K_{1}$ is $0.2, K_{2}$ is $0.3, K_{3}$ is 0.2 , and $K_{4}$ is 0.4 . The weights of criteria probability are obtained from 
summarizing questionnaires answer that be written by stock experts. Signal buy will appear when the total probability value of buy is greater than 0.5 , signal sell will appear when the total probability of sell is greater than 0.5 , and signal hold will appear when the total probability of sell and hold is 0.5. Signal hold means to not buy or sell stocks.

\section{SYSTEM DEVELOPMENT}

We use the following methodology for system development: first we collect historical data stock. Next, to figure out the requirements we asks experts to take a questionnaire. At the final step, we design the system based on the questionnaire.

\subsection{Historical Stock Data Collection}

In develop decision support system application of stock recommendation, the main thing most needed is stock data. Stock data is used as input data that will be processed and finally produce stock transaction recommendation. Stock data used includes historical stock data for last six months. Stock data can change every second, so, to produce a proper result, stock data used must be real time. Stock data is taken from Bursa Efek Indonesia (BEI) directly. Application developer cooperated with PT Tri Ultima Solusindo to get the stock data in a real time way. PT Tri Ultima Solusindo is a software house that develops online trading based on any platform, such as desktop application, website, mobile application, and mobile website.

\subsection{Questionnaire}

To more figure out the problem, developer asks several stock experts to take some questionnaire. Stock experts involved must have an experienced at least for three years in stock trade. They are from PT. Kresna Securities, PT. Universal Broker, PT. Kontakperkasa Darmawan, PT. Soe Gee Futures, and PT. Interpan Pasifik Group. There are two kinds of questionnaire, that is pre-implementation questionnaire and postimplementation questionnaire. Pre-implementation questionnaire must do before implementation of system, while post-implementation questionnaire must do after implementation of system. The main questions in pre-implementation questionnaire are technical analysis indicator that most often used and average profit percentage in one month from stock trade. Whereas, the goal of post-implementation questionnaire are to analyze advantages felt by stock experts from the use of decision support system application of stock recommendation and to ask some suggestion to improve developed application.

\subsection{System Design}

System design is the process of representing the result of analysis into a form that is more easily understood. In this case, system design is defined with a flowchart and context diagram. Flowchart is a type of diagram that represents the processes, showing the steps as boxes of various kinds, and connected by arrows. Flowcharts help visualize what is going on and thereby help the viewer to understand a process. Flowchart of decision support system application of stock recommendation is shown in the Figure 5.

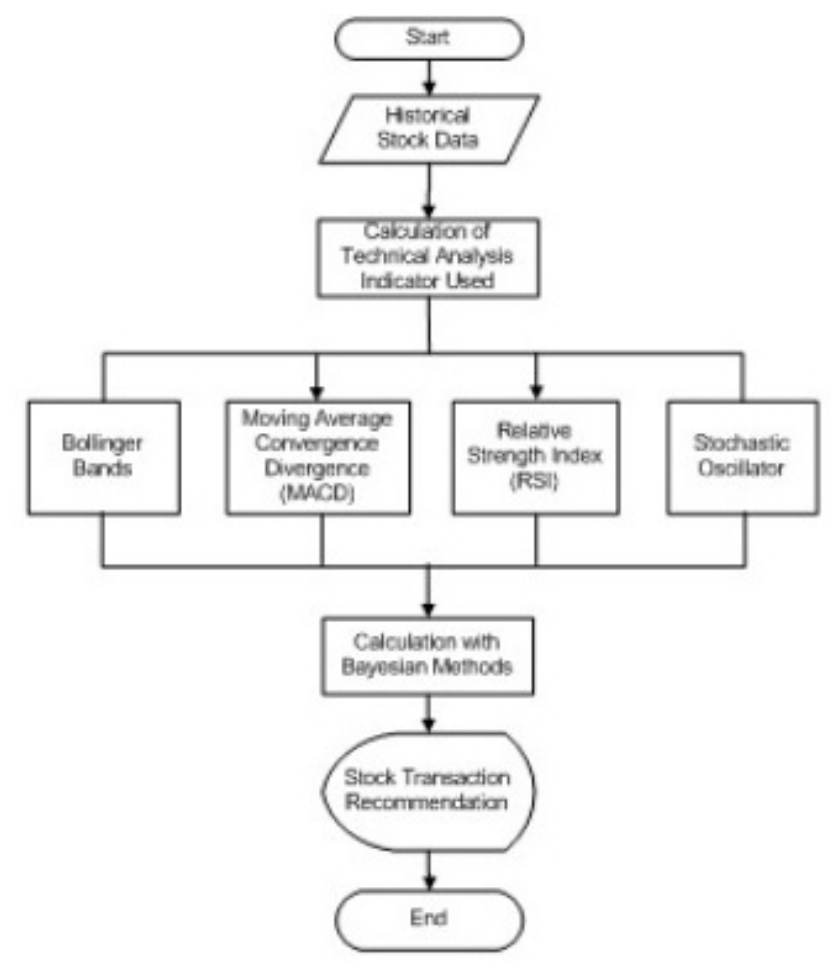

Figure 5. System Flowchart

Steps in designing this application based on flowchart in Figure 5 are as follows:

(1) create a connection to take historical stock data from BEIs server;

(2) put formula of technical analysis indicators used into coding page and program will do calculation based on that formula automatically;

(3) show the calculation results of technical analysis into web page, and it does also be input data of next calculation with Bayesian methods;

(4) put formula of Bayesian methods into coding page and program will do calculation based on formula that has been written automatically;

(5) show the results of calculation with Bayesian methods into web page as recommendation for users or traders. 
Beside flowchart, system design also defined with a context diagram. Context diagram is a diagram that represents the actors outside a system that could interact with that system. This diagram is the highest level view of a system. Context diagram of a decision support system application of stock recommendation is shown in the Figure 6.

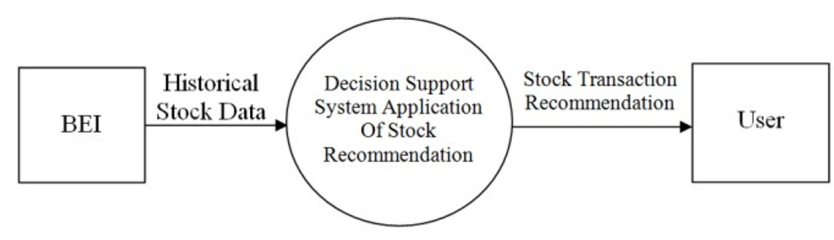

Figure 6. Context Diagram

The context diagram in Figure 6 shows that BEI give historical stock data into decision support system application of stock recommendation. The system will process that data and produce output some recommendation of stock transaction for users (traders).

\section{RESULTS AND DISCUSSION}

In this section, we present implementation of the system, some presentations of our proposed system. At the end of this section, we discuss the performance of of the proposed system.

\subsection{Implementation}

Developed decision support system application of stock recommendation has been hosted into website. Hardware required to run this web application are Personal Computer (PC) or notebook with minimum specifications: $1 \mathrm{GHz}$ processor, $512 \mathrm{Mb}$ RAM, $20 \mathrm{~Gb}$ hard disk, keyboard and mouse (or others similar) as input tools. Besides, it is also required internet connection with speed minimum $200 \mathrm{kbps}$. The software required for run this application well are: browser application (option: Internet Explorer $6+$, Firefox 1.5+, Safari 3+, Chrome 3+, or Opera $9+$ ), and Java Applet 1.2+ to support chart display.

\subsection{Application Presentations}

This application has four web pages, which are Home page, Technical Analysis page, Decision Support System (DSS) page, and Contact Us page. Home page contains a brief explanation about this decision support system application of stock recommendation. Technical Analysis page contains chart of technical analysis indicator used (Figure 7). Chart shown is the chart of stock listed on the left side of the screen. Users can type any local stock there and chart will be changes automatically. DSS page contains list of default stock (LQ-45s stock) with some data concerned, the calculation results of each indicator used (represented by MACD for Moving Average Convergence Divergence indicator, $\mathrm{BB}$ for Bollinger Bands indicator, RSI for Relative Strength Index indicator, and SO for Stochastic Oscillator), and recommendation from Bayesian method calculation that represented by DSS. There are three possible result from this method, Hold, Buy, and Sell. Hold means this application recommend user to hold the stock (not buy and not sell). Result buy recommend user to buy the stock, meanwhile result sell recommend user to sell the stock. Users can always add or change any stock they want by type it on stock column. The DSS page is shown in Figure 8. The last is Contact Us page. Contact Us page contains contact person who can be contacted by email, contact number, and office address. Existences of Contact Us page are for users who want to give any critics and advices, or need further information about this application.

\subsection{Evaluation}

Evaluation is the process of determining the value or worth of an application. The primary purpose of evaluation is to know whether developed decision support system application of stock recommendation can run well and useful for all users. Evaluation has done by ask some people to be a respondent. Respondents asked to try this application by access it through internet network.

After respondents try all features available in this application, respondents are asked to fill a questionnaire. The questionnaire contains four questions, which is each question represents one point of evaluation. Four points of evaluation such as:

(1) Accuracy level of indicators signal reading;

(2) The benefits perceived by respondents;

(3) Accuracy level of stock transaction recommendation at DSS page and DSS column; and last

(4) The interest level and simplicity to operate application over user interface of application. Result of questionnaires answer by stock experts which has been summarized in Figure 9.

In Figure 9, the blue one indicates that respondents give positive opinions about the point of evaluation, while the red one indicates the respondents give negative opinions. From the evaluation chart, known that $80 \%$ of respondents said that application give an accurate recommendation like what they read on technical analysis chart. $90 \%$ of respondents said that application can be useful for beginner traders 
Web-Based Decision Support Systems Application of Stock Recommendation Using Bayesian Methods • 7

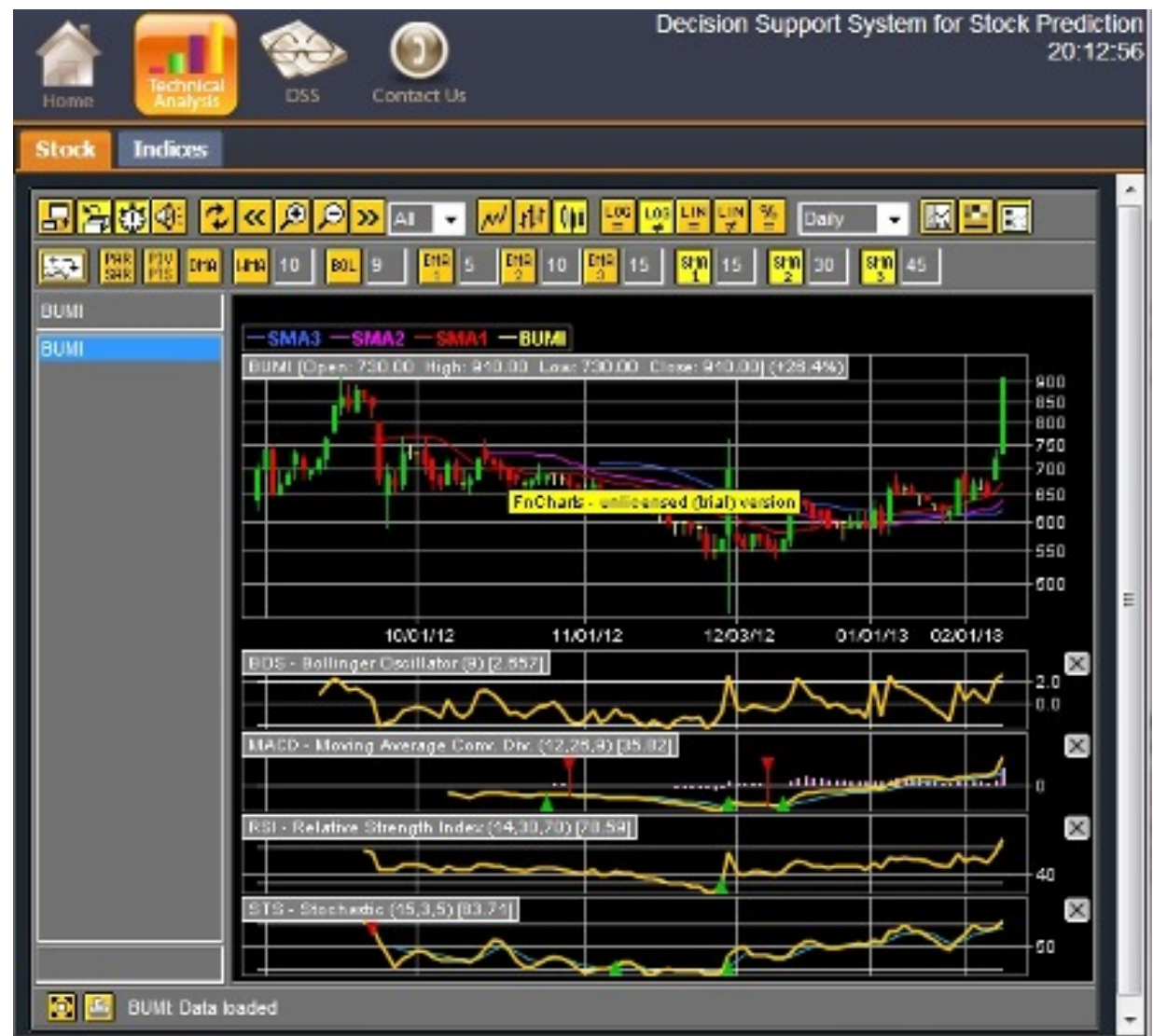

Figure 7. Technical Analysis Page

\begin{tabular}{|c|c|c|c|c|c|c|c|c|c|}
\hline & & (9) & & & & sion St & ort Sys & for $S$ & $\begin{array}{r}\text { k Pred } \\
19:\end{array}$ \\
\hline No & Stock & Name & Last & Open & MACD & BB & RSI & so & Dss \\
\hline 1 & MUI & Astra Agro Lestari Tbk. & 19,000 & 18,900 & HOLD & HOLD & Buy & SELL & HOLD \\
\hline 2 & ADRO & Adaro Energy Tblk. & 1,630 & 1,610 & HOLD & HOLD & Bur & SEL & HOLD \\
\hline 3 & MKRA & AKR Corporindo Tblk. & 4,175 & 4,150 & HOLD & HOLD & SELL & SELL & HOLD \\
\hline 4 & ANTM & Aneka Tambang (Persero)... & 1,360 & 1,370 & HOLD & HOLD & Bur & SELL & HOLD \\
\hline 5 & ASII & Astra International Tble. & 7,750 & 7,800 & HOLD & HOLD & SELL & SELL & HOLD \\
\hline 6 & ASRI & Alam Sutera Realty Tbk. & 840 & 850 & HOLD & HOLD & SELL & SELL & HOLD \\
\hline 7 & BBCA & Bank Central Asta Tbk. & 10,000 & 10,000 & HOLD & HOLD & SELL & SELL & HOLD \\
\hline 8 & BBMI & Bank Megara Indonesia (P... & 4,375 & 4,325 & HOLD & HOLD & SELL & SELL & HOLD \\
\hline 9 & BBRI & Bank Rakyat Indonesta (P... & 8,550 & 8,750 & HOLD & HOLD & SELL & SELL & HOLD \\
\hline 10 & BDMI & Bank Danamon Indonesia ... & 5,950 & 6,000 & HOLD & HOLD & SELL & SELL & HOLD \\
\hline 11 & BमाT & Bhakti Investama Tbk. & 490 & 495 & HOLD & HOLD & Bur & SELL & HOLD \\
\hline 12 & BJBR & Bank Pembangunan Daera... & 1,220 & 1,220 & HOLD & HOLD & SELL & SELL & HOLD \\
\hline 13 & BKSL & Sentul City Tbk. & 250 & 250 & HOLD & HOLD & SELL & SELL & HOLD \\
\hline 14 & BMRI & Bank Mandiri (Persero) Tblk. & 9,100 & 9,050 & HOLD & HOLD & SELL & SELL & HOLD \\
\hline 15 & BORU & Borneo Lumbung Energi \&.... & 570 & 530 & HOLD & HOLD & Bur & SEL & HOLD \\
\hline 16 & BSDE & Bumi Serpong Damai Tbk. & 1,420 & 1,420 & HOLD & HOLD & SELL & SELL & HOLD \\
\hline 17 & BUMI & Bumi Resources Ibk & 910 & 730 & HOLD & HOLD & SELL & SELL & HOLD \\
\hline 18 & BWPT & BW Plantation Tbk. & 1,320 & 1,300 & HOLD & HOLD & Buy & SELL & HOLD \\
\hline 19 & CPIN & Charoen Polkphand Indon... & 4,150 & 4,000 & HOLD & HOLD & SELL & SEL & HOLD \\
\hline 20 & ELTY & Bakrieland Development T... & 59 & 55 & HOLD & HOLD & SELL & SELL & HOLD \\
\hline
\end{tabular}

Figure 8. DSS Page

to help them in reading technical analysis chart. Total respondents who agree with recommendation in column DSS is $70 \%$ of all. All respondents do not

INKOM, Vol. 8, No. 1, Article 302, Publication date: May 2014. 


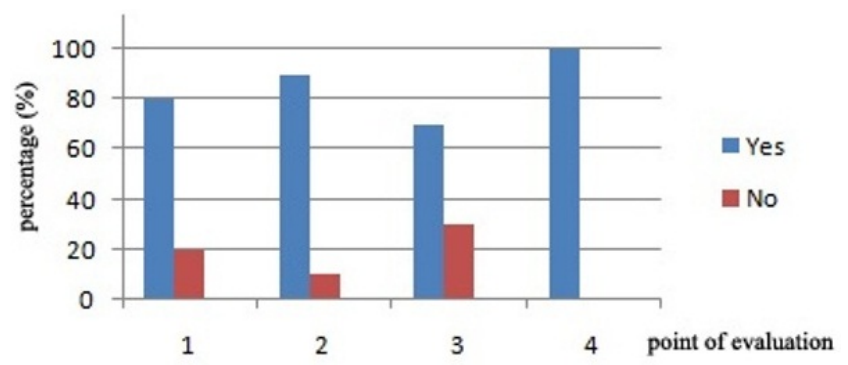

Figure 9. Evaluation Chart

have any problem in operating the application and user interface.

Beside evaluation by some stock experts, evaluation also did by compare recommendation given by application with the fact. The fact can be seen a few days after recommendation is given. Comparing is done for seven days on LQ-45 stocks. According to broker of PT. Kresna Securities, seven days is a good time to do stock price comparing. This evaluation give the result that accuracy of recommendation given by application is $87,37 \%$. Mathematically, it is obtained by formula calculation as follows in Eq. 14:

By the results, it means developed decision support system application of stock recommendation is still not fulfill the goal of application. That is because the standard minimum of accuracy level is just $87,37 \%$, that is still under $100 \%$. But this doesnt reduce benefit for beginner traders in help them to read technical analysis indicator chart.

Evaluation also made with compare this application with other existing applications. The evaluation result shown in Table I.

\section{CONCLUSION}

Technical Analysis feature in a decision support system application of stock recommendation is useful to show technical analysis chart for all users (traders). Technical analysis chart commonly needs by all traders in stock trading. By use DSS feature in this application, users can be helped in read signal of technical analysis indicator chart, especially for beginner traders who do not have much experience in stock trade. Signal scope given in this application is only for Bollinger Bands indicator, MACD indicator, RSI indicator, and Stochastic Oscillator indicator. This application also can give stock transaction recommendation for traders. The purpose is to help traders in making stock transaction decision that give maximum profit for them and avoid any risk of loss. Based on evaluation that has been done, accuracy level of recommendation given by application is $87.37 \%$. The lack of this accuracy level can be caused
Table I. Comparison to Existing Systems

\begin{tabular}{ll}
\hline $\begin{array}{l}\text { Application } \\
\text { Name }\end{array}$ & Description \\
\hline Online Trading & (1) Owned by securities company. \\
& (2) Can be accessed only by \\
securitys member. \\
(3) Give real time information \\
about stocks and forex. \\
(4) Can be accessed via desktop, \\
web, and mobile devices.
\end{tabular}

Virtual Trading

(1) Using virtual money to make a transaction.

(2) Can be used as an exercise tools for beginners stock player.

(3) Real Meta (www.duniainvestasi.com)

(4) Display intraday data.

(5) Paid application.

(6) Manage portfolio.

(7) Automatic update with specific interval.

HOTS (Home

Online Trading (1) Provide personal portfolio.

System) by (2) Provide historical stock data.

PT. Daewoo (3) Paid application.

Securities

(4) Display bid and offer position of a stock.

(5) Equipped by tools for technical analysis.

(6) Various kinds of paid application

(7) Usually only using one indicator.

(8) Usually only provide one specific stocks code.

Probabilistic

Neural Network (1) Using Probabilistic Neural for Technical Analysis for stock investment [3]

Network to process stock.

(2) Using seven indicators.

(3) Appropriate only for big volume data, like time series data.

by varies of factors, such as discrepancy of variables used in calculation with Bayesian methods, discrepancy applying Bayesian methods in calculate stock recommendation, or discrepancy of technical analysis indicators combination used.

In order to get better result of application, more detail studies needs to be conducted. One 
of them is to review the weight of criteria probability in calculation with Bayesian methods. In addition, advised to study other calculation methods that maybe suitable to produce an accurate stock recommendation. Furthermore, also advised to review technical analysis indicators used in improving decision support system application of stock recommendation.

\section{ACKNOWLEDGMENT}

This research is funding by Lembaga Penelitian dan Pengabdian Masyarakat (LPPM) Universitas Kristen Krida Wacana with contract No. 14/UKKW/LPPMFT/Lit/XI/2012.

\section{Daftar Pustaka}

[1] D. Mulyana, "Analisis likuiditas saham serta pengaruhnya terhadap harga saham pada perusahaan yang berada pada indeks lq45 di bursa efek indonesia," Jurnal Magister Manajemen, vol. 4, no. 1, Maret 2011.

[2] A. Z. R. Langi, S. Pitara, and Kuspriyanto, "Stock prices trends analysis using wavelet transform," in Cloud Computing and Social Networking (ICCCSN), 2012 International Conference on, April 2012, pp. 14.

[3] Tristiyanto, "Pemilihan analisis teknis dalam berinvestasi saham menggunakan probabilistic neural network," in Seminar Nasional Sains dan Teknologi, Agustus 2007.
[4] Rajan, S. G.B., and S. Parimala, "Stock price movement through technical analysis : Emperical evidence from the fast moving cunsomer goods (fmcg) sector," Paripex-Indian Journal of Research, vol. 2, no. 2, February 2013.

[5] M. Samsul, Pasar Modal dan Manajemen Portofolio. Erlangga, 2006.

[6] P. Ou and H. Wang, "Prediction of stock market index movement by ten data mining techniques," Modern Applied Science, vol. 3, no. 12, December 2009.

[7] K. Hendarto, Belajar Trading: Pahami Trading Sebelum Anda Memulai. Andi Offset, 2005.

[8] K. S. Kannan, P. S. Sekar, M. M. Sathik, and P. Arumugam, "Financial stock market forecast using data mining techniques," in Proceedings of the International Multiconference of Engineers and computer scientists, vol. 1, 2010.

[9] G. Cohen, A. Kudryavstev, and S. Hon-Snirpractice : Is it technical or fundamental," Journal of Applied Finance and Banking, vol. 1, no. 3, 2011.

[10] T. Hidayat, Buku Pintar Investasi Reksadana, Saham, Opsi Saham, Valas, \& Emas. Mediakita, 2010.

[11] D. Wira, Analisis Teknikal Untuk Profit Maksimal. PT Exceed, 2010.

[12] H. Syamsir, Solusi Investasi di Bursa Saham Indonesia. PT Elex Media Komputindo, 2004.

[13] S. Widoatmodjo, Cara Cepat Memulai Investasi Saham: Panduan Bagi Pemula. PT Elex Media Komputindo, 2007.

[14] N. Marimin \& Maghfiroh, Aplikasi Teknik Pengambilan Keputusan dalam Manajemen Rantai Pasok. IPB Press, 2011. 
10 - Nina Sevani and Maria Ariesta

INKOM, Vol. 8, No. 1, Article 302, Publication date: May 2014. 